\title{
Kloning gen virulen Streptococcus agalactiae sebagai bahan dasar vaksin rekombinan
}

\section{Cloning of virulence gene of Streptococcus agalactiae as recombinant vaccine}

\author{
Sutanti $^{1}$, Retno Damayanti Soejoedono ${ }^{1}$, Irvan Faizal ${ }^{*}$ \\ ${ }^{1}$ Program studi Bioteknologi, Institut Pertanian Bogor \\ Kampus IPB Dramaga Bogor, Jawa Barat 16680 \\ ${ }^{2}$ Pusat Teknologi Produksi Pertanian - Balai Pengkajian dan Penerapan Teknologi \\ Jalan MH. Thamrin No. 8, Jakarta Pusat 10340 \\ Surel: irvan.faizal@bppt.go.id
}

\begin{abstract}
Streptococcus agalactiae has emerged as an important pathogen that affects Nile tilapia in Indonesia aquaculture. Vaccination is one of the most effective tools for enhancing host defense and protecting fish from pathogens. DNA vaccine is a third generation of vaccines based on the gene encoding a vaccine antigen rather than the antigen itself. Mga is DNA-binding protein that activates expression of several important virulence gene, including those encoding M protein (emm), C5a peptidase (SCPA), and mga. The goals of this study were to isolate and molecular characterize the mga gene of local isolate of $S$. agalactiae to support the development of DNA vaccine. Local bacterial strain was isolated from Nile tilapia farming in West Java, Indonesia. Bacterial identification was accomplished by PCR, using $16 \mathrm{~S}$ rRNA primers, which revealed the 1,500 bp PCR product. Mga gene isolation was accomplished by PCR using mga gene $S$. agalactiae SAF and SAR- specific primers, which revealed the 1,494 bp PCR product. Mga gene was cloned into pGEM T-easy and sequenced using M13 primers. SalI and NotI restriction enzymes were used to digest the pGEM T-easy vector containing mga gene. Mga gene was cloned into pMBA containing beta actin promoter of Japanese medaka. The 16S rRNA sequence analyses confirmed that the local bacteria was $97 \%$ similarity with $S$. agalactiae strain 15-92MPnew. The nucleotide sequence analyses confirmed that the clones were contained $98 \%$ similarity with M protein mga S. agalactiae. The mga gene controlled by MBA promoter has constructed successfully as a candidate of DNA vaccine to against $S$. agalactiae infection in Nile tilapia.
\end{abstract}

Keywords: DNA vaccine, Streptococcus agalactiae, mga gene, Oreochromis niloticus, recombinant DNA

\begin{abstract}
ABSTRAK
Streptococcus agalactiae merupakan patogen penting yang mempengaruhi budidaya ikan nila di Indonesia. Vaksinasi merupakan salah satu metode yang paling efektif untuk meningkatkan pertahanan dan melindungi ikan dari patogen. Vaksin DNA adalah vaksin generasi ketiga yang mengandung gen penyandi antigen vaksin. Mga adalah protein DNA-binding yang mengaktifkan ekspresi beberapa gen virulensi, termasuk M protein (emm), C5a peptidase (SCPA) dan mga. Tujuan dari penelitian ini adalah untuk mengisolasi dan karakterisasi secara molekuler gen mga dari isolat lokal $S$. agalactiae untuk mendukung pengembangan vaksin DNA. Identifikasi bakteri dilakukan dengan PCR, menggunakan primer 16S rRNA dengan produk PCR $1.500 \mathrm{bp}$. Isolasi gen mga dilakukan dengan metode PCR menggunakan primer SAF dan SAR dengan ukuran target $1.494 \mathrm{bp}$. Gen mga dikloning ke vektor pGEMT-easy dan disekuensing menggunakan primer M13. Enzim Sal I dan Not I digunakan untuk memotong gen mga dari vektor pGEMT- easy, selanjutnya gen mga dikloning ke vektor pMBA yang mengandung promoter betaaktin ikan medaka Jepang. Berdasarkan analisis menggunakan gen 16S rRNA diperoleh bahwa sampel memiliki kesamaan $97 \%$ sebagai S. agalactiae. Analisis sekuen nukleotida menunjukkan bahwa klon mengandung gen mga dengan $98 \%$ kesamaan dengan M protein mga S. agalactiae. Konstruksi mga gene yang dikendalikan oleh promoter MBA telah berhasil dibuat dan ini merupakan kandidat vaksin DNA untuk mengendalikan infeksi $S$. agalactiae pada ikan nila.
\end{abstract}

Kata kunci: vaksin DNA, Streptococcus agalactiae, gen mga, Oreochromis niloticus, DNA rekombinan 


\section{PENDAHULUAN}

Vaksin DNA memiliki beberapa keuntungan dibandingkan dengan vaksin konvensional. Pada umumnya vaksin konvensional tergantung pada terbentuknya antibodi dalam mencegah penyakit infeksi, namun tidak mampu merangsang respons imun seluler. Vaksin DNA selain dapat merangsang respons imun humoral melalui pembentukan antibodi, juga dapat merangsang imun seluler melalui aktivasi sel T (cell-mediated response immune) sehingga dapat memberikan kekebalan terhadap mikroba patogen intraseluler. Vaksin DNA dapat diproduksi dalam waktu singkat dalam jumlah besar (Abdulhaqq \& Weiner, 2008; Kurath, 2008; Tonheim et al., 2008). Vaksin DNA mempunyai keunggulan dibandingkan dengan vaksin konvensional, yaitu dapat merangsang respons imun humoral dan seluler melalui inokulasi DNA yang mengandung sekuen plasmid DNA yang bersifat imunogenik (Pokorna et al., 2008; Wang et al., 2008; Patel et al., 2010).

Vaksin DNA dikonstruksi melalui kloning gen, yang mengkode bagian protein atau sub bagian dari organel organisme. Informasi mengenai gen yang berperan dalam proses virulensi bakteri sangat dibutuhkan untuk mendapatkan produk vaksin DNA yang efektif dan bersifat imunogenik. Potongan molekul DNA plasmid rekombinan sebagai vaksin DNA, terdiri atas basa-basa nitrogen. Basa-basa nitrogen tersebut membentuk kodon yang menyandi informasi, yang selanjutnya disebut gen. Keamanan dan fungsi mendasar dari pembuatan vaksin DNA adalah gen penyandi antigen harus terekspresi, mampu menimbulkan respons antibodi dan mampu melawan patogen (Nuswantoro et al., 2012).

Salah satu potensi pengembangan vaksin DNA bakteri pada bidang perikanan yang dapat diproduksi melalui teknologi DNA rekombinan adalah vaksin DNA untuk Streptococcus. Bakteri Streptococcus agalactiae merupakan bakteri penyebab penyakit streptococciasis pada ikan dan menyebabkan kematian mencapai $80-100 \%$ (Hardi et al., 2013). Penyakit streptococcosis merupakan penyakit berspektrum luas karena dapat menyerang ikan air tawar seperti ikan nila dan gurami, dan pada ikan air laut seperti ikan kakap dan ikan kerapu. Pola penyerangan bakteri ini terutama pada ikan ukuran dewasa yang siap panen sehingga menimbulkan kerugian yang besar. Bakteri ini merupakan golongan bakteri penyebab meningitis (Eyngor et al., 2008; Johri et al.. 2006). Menurut Hardi et al. (2013), bakteri $S$. agalactiae hidup di organ hati, ginjal, otak dan darah. Infeksi bakteri $S$. agalactiae dapat menyebabkan kematian sebesar $90 \%$ pada ikan nila dengan berat rata-rata $40 \mathrm{~g}$ yang diuji tantang S. agalactiae pada dosis $10^{7} \mathrm{cfu} / \mathrm{ikan}$ selama enam hari (Evans et al., 2009).

Sekuen lengkap genom untuk bakteri Streptococcus agalactiae sudah berhasil ditemukan sehingga identifikasi gen yang berperan dalam virulensi bakteri ini lebih mudah untuk dilakukan. Gen mga merupakan gen virulen dominan pada grup A dan B bakteri Streptococcus. Mga adalah DNA-binding protein yang mengaktivasi beberapa gen virulen untuk mengkode protein $\mathrm{M}$, C5a peptidase dan protein Mga (Prieto et al., 2012). Penelitian ini bertujuan untuk melakukan kloning gen virulen bakteri S. agalactiae isolat lokal untuk mendukung pengembangan vaksin DNA.

\section{BAHAN DAN METODE}

\section{Isolasi bakteri dan genom DNA Streptococcus agalactiae}

Isolat bakteri yang digunakan merupakan isolat lokal yang diisolasi dari ikan nila sakit di lingkungan budidaya ikan di Jawa Barat. Kultur bakteri yang diduga $S$. agalactiae dilakukan pada media rain heart infusion agar (BHIA, Merck), inkubasi pada suhu $30{ }^{\circ} \mathrm{C}$ selama 48 jam. Ekstraksi DNA bakteri dilakukan menggunakan metode lysis by alkali sesuai metode Sambrook et al. (1999). Deteksi bakteri dan identifikasi bakteri $S$. agalactiae dilakukan menggunakan polymerase chain reaction (PCR) dengan primer 16S rRNA. Hasil PCR kemudian dikloning ke vektor pGEM-T easy dan plasmid positif disekuensing. Selanjutnya hasil sekuensing dianalisis menggunakan nukleotida BLAST dengan data di GenBank.

\section{Desain primer gen mga}

Desain primer untuk mengamplifikasi gen mga dilakukan dengan memperhatikan data sekuen gen mga protein dari bakteri $S$. agalactiae (GenBank: CP003919.1). Primer didesain menggunakan program GENETYX version 7 dan Primer Premier 6. Proses desain primer juga memperhatikan pola pemotongan enzim dari vektor yang akan digunakan. Primer yang telah didesain kemudian digunakan untuk mengamplifikasi gen mga $S$. agalactiae. Siklus PCR disesuaikan dengan hasil suhu annealing 
dari primer dengan metode gradient PCR. Hasil amplifikasi kemudian diseparasi menggunakan elektroforesis dengan $0,8 \%$ gel agarosa dan divisualisasi dengan gel dokumentasi.

\section{Isolasi dan kloning gen mga}

Isolasi gen mga dilakukan dengan metode PCR menggunakan satu pasang primer spesifik yang didesain pada penelitian ini, yaitu SAF (5'GTCGACTTGCTATTTGATTTTCTCG 3') dan SAR (5' GCGGCCGGCATTTTTTGAAA TATATTCA 3'). Komposisi reaksi PCR adalah $1 \mu \mathrm{L}$ DNA genom bakteri, $1 \mathrm{x}$ bufer Taq, $2 \mathrm{mM}$ dNTP mix, 20 pmol primer forward, 20 pmol primer reverse, $2 \mathrm{U}$ enzim dream Taq polimerase (Fermentas), dan $\mathrm{ddH}_{2} \mathrm{O}$ dengan volume reaksi 10 $\mu \mathrm{L}$. PCR dilakukan pada kondisi pra-denaturasi $95{ }^{\circ} \mathrm{C} 5$ menit, denaturasi $95{ }^{\circ} \mathrm{C} 30$ detik, penempelan primer pada $42,5{ }^{\circ} \mathrm{C} 30$ detik dan pemanjangan $72{ }^{\circ} \mathrm{C}$ satu menit, dengan 30 siklus, dan pemanjangan akhir pada $72{ }^{\circ} \mathrm{C}$ lima menit, diikuti dengan $15^{\circ} \mathrm{C}$ selama sepuluh menit. Hasil PCR kemudian divisualisasi pada gel agarosa $1 \%$ dan dilakukan purifikasi menggunakan kit DNA gel extraction (GenAid).

Fragmen DNA hasil purifikasi selanjutnya dikloning menggunakan vektor pGEM-T easy (Ampr; Promega). Tahapan kloning meliputi ligasi dan transformasi. Komposisi reaksi ligasi meliputi $5 \mu \mathrm{L}$ larutan DNA, 0,5 $\mu \mathrm{L}$ pGEM-T easy, $6,5 \mu \mathrm{L} 5 \mathrm{x}$ bufer ligasi, dan $1 \mu \mathrm{L}$ enzim T4 DNA ligase (Fermentas). Plasmid yang dihasilkan dinamai pT-gma. Inkubasi dilakukan selama satu jam pada suhu ruang. Prosedur transformasi dilakukan mengikuti metode Sambrook et al. (1999) yang telah dimodifikasi dan menggunakan kompeten sel Eschericia coli DH5a. Seleksi transforman dilakukan dengan seleksi koloni biru putih pada media LA yang mengandung $20 \mathrm{mM} \mathrm{MgSO}$, X-gal, IPTG dan antibiotik ampisilin $100 \mu \mathrm{g} / \mathrm{mL}$. Seleksi koloni bakteri yang membawa plasmid hasil ligasi dilakukan dengan PCR koloni. Koloni bakteri yang positif membawa fragmen gen mga selanjutnya dikultur, dan kemudian dilakukan isolasi plasmid.

\section{Isolasi Plasmid}

Isolasi plasmid dilakukan menggunakan kit plasmid mini extraction (GenAid) dengan prosedur sesuai manual. Kultur bakteri sebanyak $1,5 \mathrm{~mL}$ disentrifugasi pada $12.000 \mathrm{rpm}$, suhu 4 ${ }^{\circ} \mathrm{C}$ selama dua menit. Sebanyak $250 \mu \mathrm{L}$ bufer RP ditambahkan pada pelet bakteri kemudian dihomogenkan. Bufer LN sebanyak $250 \mu \mathrm{L}$ ditambahkan dan tabung mikro dibolak-balik 3-4 kali. Bufer NP sebanyak $350 \mu \mathrm{L}$ ditambahkan dan tabung mikro dibolak-balik 3-4 kali kembali, kemudian dilakukan sentrifugasi $13.000 \mathrm{rpm}$ suhu $4{ }^{\circ} \mathrm{C}$ selama sepuluh menit. Supernatan difiltrasi menggunakan binding column, dilakukan pencucian menggunakan $500 \mu \mathrm{L}$ bufer DP dan sentrifugasi $13.000 \mathrm{rpm}$ suhu $4{ }^{\circ} \mathrm{C}$ selama 1 menit. Penambahan bufer $700 \mu \mathrm{L}$ WP ke dalam kolom, disentrifugasi, dan supernatan dibuang. Sentrifugasi diulang untuk menghilangkan sisa bufer WP dan kolom dipindahkan ke tabung mikro yang baru. Sebanyak $50 \mu \mathrm{L}$ bufer EP ditambahkan untuk mengelusi plasmid DNA. Plasmid DNA divisualisasi menggunakan gel agarosa $0,8 \%$. Hasil isolasi plasmid kemudian diverifikasi dengan metode PCR dan restriksi dengan enzim.

\section{Analisis sekuen gen mga}

Proses analisis sekuensing plasmid pT-mga dilakukan menggunakan primer M13 forward (5'CGCCAGGGTTTTCCCAGTCACGAC 3') dan M13 reverse (5' TCACACAGGAAACAGC TATGAC 3'). Volume reaksi amplifikasi untuk sekuensing sebanyak $20 \mu \mathrm{L}$ dengan komposisi $2 \mu \mathrm{L}$ Ready Reaction mix; $3 \mu \mathrm{L}$ bufer Bigdye; $6,4 \mu \mathrm{L}$ primer M13 forward atau reverse dengan konsentrasi 10 pmol; 300 ng plasmid DNA dan sisanya $\mathrm{ddH}_{2} \mathrm{O}$. Program PCR yang digunakan adalah pra-denaturasi suhu $96{ }^{\circ} \mathrm{C}$ selama dua menit, dan 30 siklus dengan suhu $96{ }^{\circ} \mathrm{C}$ sepuluh detik, $50{ }^{\circ} \mathrm{C}$ selama lima detik dan $60{ }^{\circ} \mathrm{C}$ selama tiga menit. Sekuensing DNA dilakukan menggunakan mesin ABI PRISM 3100- Avant genetic analyzer. Analisis sekuen dilakukan menggunakan program GENETYX versi 7 dan sequence scanner versi 1.0. Analisis kesejajaran gen mga dilakukan menggunakan program BLAST.

\section{Pembuatan vektor pMBA}

Vektor pMBA merupakan vektor yang dilengkapi dengan promoter $\beta$-aktin ikan medaka Jepang (MBA) untuk proses ekspresi pada ikan nila. Vektor pMBA dan pT mga dilakukan double digestion menggunakan enzim Sal I dan Not I. Hasil restriksi gen mga dari vektor pT-mga yang telah dipurifikasi kemudian diligasikan pada vektor pMBA. Komposisi reaksi ligasi meliputi $5 \mu \mathrm{L}$ larutan DNA, 0,5 $\mu \mathrm{L}$ pMBA, 6,5 $\mu \mathrm{L} 5 \mathrm{x}$ bufer ligasi, dan $1 \mu \mathrm{L}$ enzim T4 DNA ligase (Fermentas). Inkubasi dilakukan selama satu jam pada suhu ruang. Sebanyak $5 \mu \mathrm{L}$ hasil reaksi 
ligasi dicampurkan ke dalam tabung mikro yang berisi sel kompeten E. coli DH5 $\alpha$. Transformasi dilakukan menggunakan kejutan panas pada suhu $42{ }^{\circ} \mathrm{C}$ selama 50 detik. Sekitar 2-3 menit setelah diinkubasi dalam es, ke dalam tabung mikro ditambahkan $900 \mu \mathrm{L}$ larutan SOC $(1,2 \mathrm{~g}$ polypeptone; 0,3 g yeast extract; $0,035 \mathrm{~g} \mathrm{NaCl}$; $0,011 \mathrm{~g} \mathrm{KCl} ; 600 \mu \mathrm{L} \mathrm{MgSO}_{4} 1 \mathrm{M}$ dan $60 \mu \mathrm{L}$

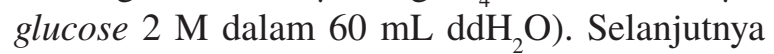
inkubasi dilakukan menggunakan shaker pada suhu $37^{\circ} \mathrm{C}$ selama satu jam. Bakteri disebar pada media LA yang mengandung $20 \mathrm{mg} / \mathrm{mL}$ antibiotik kanamisin sebagai media seleksi. Koloni yang mampu tumbuh di media tersebut kemudian digunakan untuk proses PCR koloni. Koloni yang mengandung plasmid pMBA-mga kemudian dilakukan isolasi plasmid dengan metode plasmid miniprep isolation (GenAid), restriksi enzim, PCR DNA plasmid, dan pengukuran konsentrasi plasmid menggunakan nannodrop.

\section{HASIL DAN PEMBAHASAN}

\section{Isolasi bakteri dan genom DNA $S$. agalactiae}

Bakteri yang diduga $S$. agalactiae berhasil diisolasi dari ikan nila sakit dengan gejala klinis adalah ikan lemah, warna gelap, nafsu makan menurun, exopthalmia (mata menonjol), whirling atau hilang keseimbangan. Gejala internal yang muncul adalah adanya pembengkakan limpa, hati, dan organ saluran pencernaan. DNA genom bakteri berhasil diisolasi menggunakan metode lysis by alkali. Amplifikasi menggunakan primer
16S rRNA menghasilkan fragmen DNA dengan ukuran 1.500 bp (Gambar 1). Hasil amplifikasi sebesar 1.500 bp pada masing-masing sampel dilakukan proses purifikasi untuk mendapatkan gen $16 \mathrm{~S}$ rRNA yang lebih murni.

Gen 16S rRNA berhasil diligasikan ke vektor kloning pGEM-T easy dan transformasi menggunakan sel kompeten E. coli DH5 $\alpha$ dengan metode heat shock. Plasmid yang positif mengandung gen 16S rRNA berhasil disekuensing dengan ukuran sekuen 961 bp. Berdasarkan hasil homologi metode BLAST N diketahui bahwa sampel sekuen gen 16S rRNA sampel 16sa1 memiliki kesamaan dengan query cover $97 \%$ sebagai $S$. agalactiae strain 19-42 MP new (no. aksesi GenBank: EU075070.1). Hal ini berarti bakteri yang diisolasi merupakan bakteri patogen S. agalactiae.

\section{Desain primer gen virulen}

Primer untuk mengisolasi gen mga telah berhasil didesain dengan penambahan situs restriksi dua jenis enzim (SalI dan NotI). Susunan primer adalah sebagai berikut: SAF (5'GTCGACTTGCTATTTGATTTTCTCG3') dan SAR CGGCCGGCATTTTTTGAAATATA TTCA 3'). Susunan basa yang dicetak tebal yaitu GTCGAC merupakan situs pemotongan enzim SalI, sedangkan GCGGCCGGCA merupakan situs pemotongan enzim NotI. Kedua enzim tersebut akan digunakan untuk proses deteksi dan restriksi insersi dari vektornya.

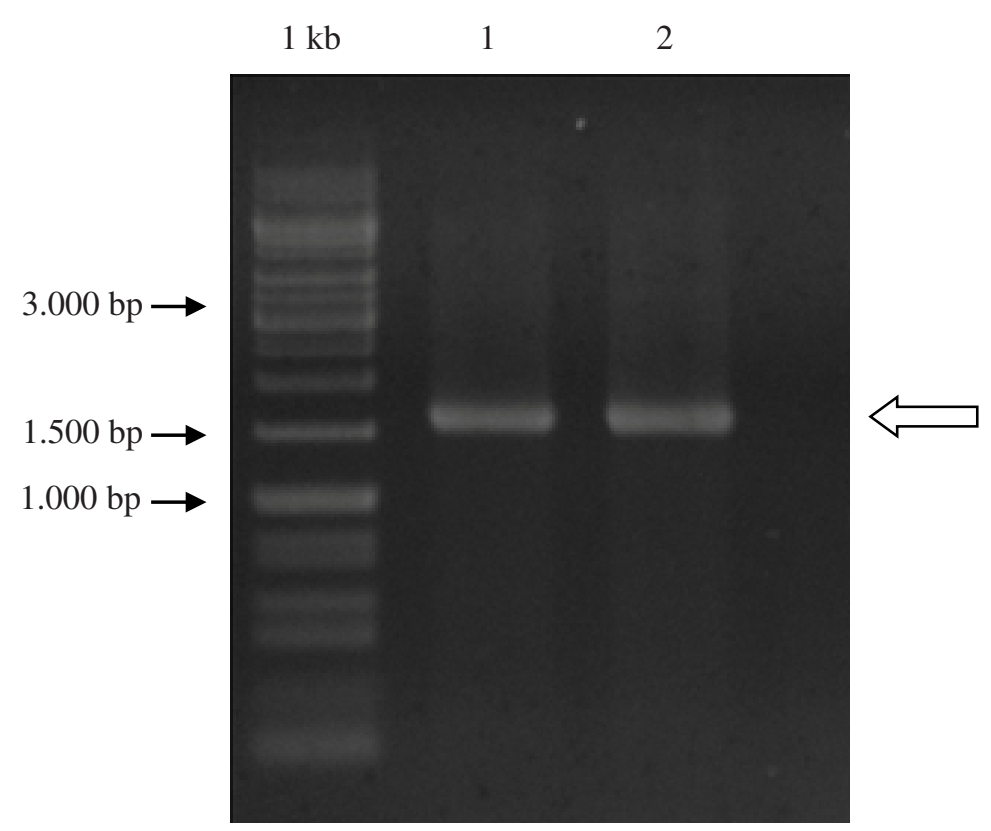

Gambar 1. Elektroforesis DNA hasil PCR menggunakan primer 16S rRNA dengan ukuran target $1.500 \mathrm{bp}$. 


\section{Isolasi dan kloning gen mga pada pGEM-T easy}

Gen mga berhasil diisolasi menggunakan metode PCR gradien dengan suhu penempelan optimal 43,5 ${ }^{\circ} \mathrm{C}$ dan berukuran $1.494 \mathrm{bp}$. Fragmen DNA hasil amplifikasi PCR (Gambar 2) tersebut diligasi dengan vektor pGEM-T easy, ditransformasi ke sel kompeten E. coli DH5 dan kemudian bakteri dikultur.

Berdasarkan hasil transformasi vektor pGEM-T easy-gen mga, diperoleh koloni sebanyak 12 koloni, yaitu delapan koloni berwarna putih dan empat koloni berwarna biru. Koloni yang berwarna putih merupakan kandidat positif bakteri yang membawa plasmid pT-mga. Masing-masing koloni putih berhasil dikultur pada media 2xYT yang mengandung antibiotik ampisilin $100 \mathrm{mg} / \mathrm{mL}$ dan dilakukan isolasi plasmid menggunakan metode kit plasmid mini preparation (GenAid).

Verifikasi transforman dilakukan dengan melakukan PCR koloni pada koloni bakteri berwarna putih. PCR koloni merupakan metode amplifikasi yang hampir sama dengan metode PCR secara umum, yang membedakan adalah template yang digunakan, pada PCR koloni menggunakan template koloni bakteri yang telah dilarutkan pada akuades steril dan dipanaskan pada suhu $99{ }^{\circ} \mathrm{C}$ selama lima menit. PCR koloni menggunakan primer gen mga yaitu primer yang sama untuk mengisolasi gen mga. Berdasarkan hasil PCR koloni diketahui bahwa terdapat empat koloni positif yang mengandung insersi gen mga, yaitu koloni 1, 2, 6, dan 8 dengan ukuran 1.494 bp, PCR menggunakan template DNA plasmid juga positif mengandung gen mga.

Verifikasi selanjutnya dilakukan menggunakan metode restriksi enzim. Plasmid pT-mga dipotong menggunakan dua jenis enzim (SalI dan NotI), dan hasil restriksi enzim dapat diamati pada Gambar 3. Double digestion SalI dan NotI plasmid pTmga menghasilkan dua potongan yaitu $3.015 \mathrm{bp}$ yang merupakan ukuran plasmid pGEM-T easy dan 1.494 bp yang merupakan ukuran gen mga.

\section{Analisis sekuen gen mga}

Plasmid pGEM-T easy-gen mga yang positif kemudian dilakukan sekuensing menggunakan primer M13. Gen mga berhasil disekuen dengan ukuran 1.494 bp. Sekuen kemudian dilakukan homologi di BLASTN website www.nlm.nih. gov dan memiliki kesamaan $98 \%$ dengan gen penyandi protein M (mga) (no. aksesi GenBank: CP_003919.1), sedangkan untuk hasil BLASTX memiliki kesamaan $92 \%$ protein $\mathrm{M}$ (mga) (no. aksesi Bank Gen: YP_006951495.1). Hasil analisis terhadap protein ini memberikan skor 423 bits dengan nilai E sama dengan 2e-123. Secara teoritis, kisaran skor $\geq 150$ bits dengan E-value $\geq$ e-04 pada analisis BLASTX menunjukkan tingkat kemiripan yang tinggi (Claveri et al., 2003). Analisis sekuen menggunakan software

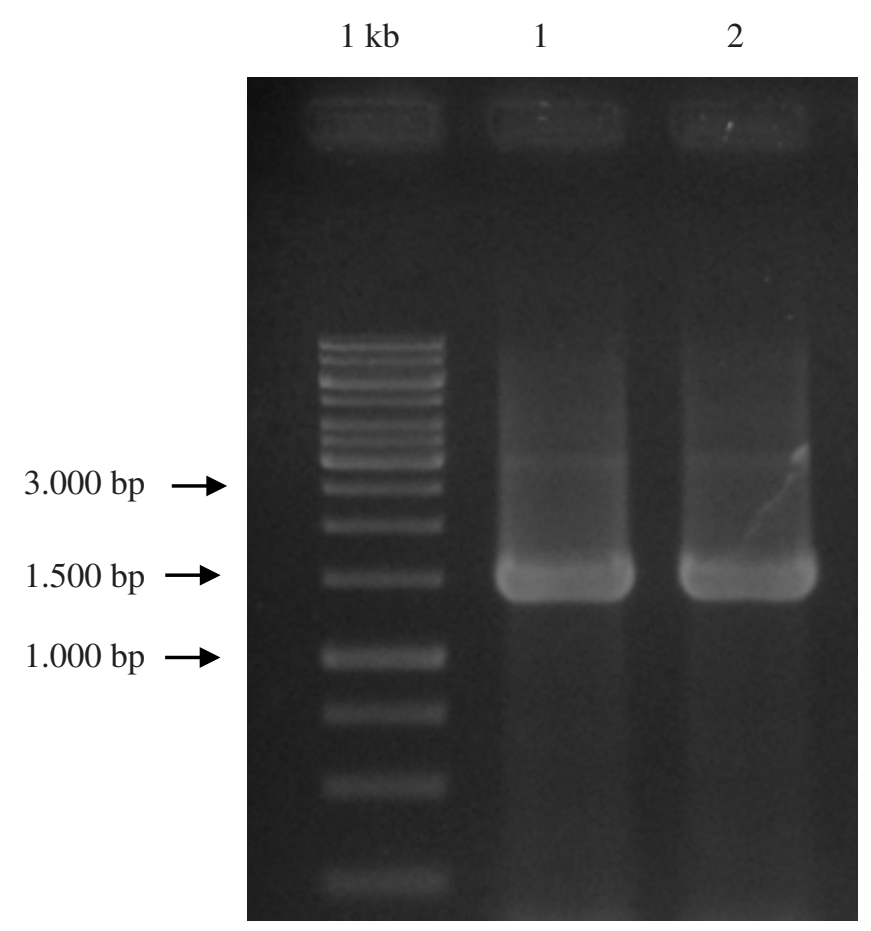

Gambar 2. Elektroforesis gen mga hasil PCR menggunakan primer SAF dan SAR dengan ukuran target 1.494 bp. 
GENETYX menunjukkan bahwa alignment sekuens partial gen mga $S$. agalactiae (dari arah forward) dengan gen mga $S$. agalactiae (no. aksesi Bank Gen NC_019048.1) (Gambar 4), sedangkan untuk hasil alignment dari arah reverse ditunjukkan pada Gambar 5. Berdasarkan hasil alignment diketahui bahwa sampel pada kajian ini memiliki kemiripan yang tinggi dengan sekuen gen mga.

\section{Kloning gen mga ke vektor pMBA}

Gen mga dan plasmid pMBA dipotong menggunakan enzim enzim SalI dan NotI. Vektor pMBA dan gen mga yeng telah dipotong dengan dua enzim, kemudian diligasikan. Berdasarkan hasil transformasi menunjukkan bahwa terdapat 59 koloni yang resisten terhadap kanamisin. Verifikasi transforman dilakukan menggunakan PCR koloni. Koloni-koloni yang positif

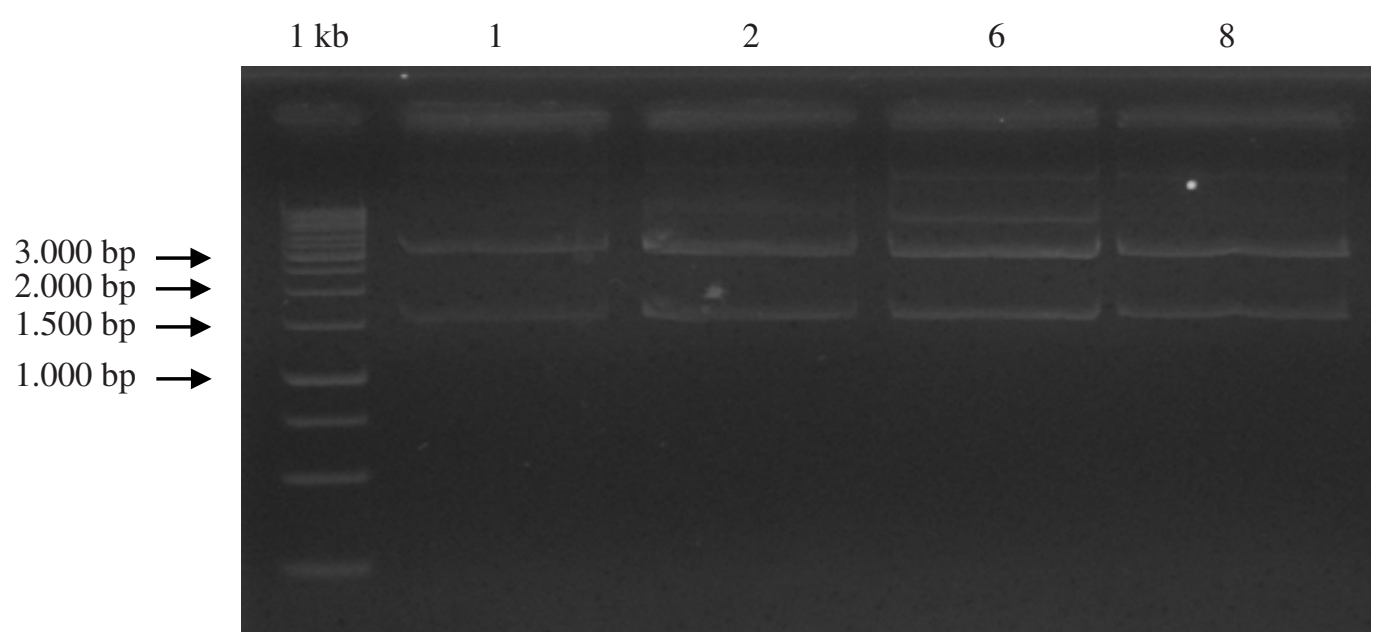

Gambar 3. Double digestion enzim SalI dan NotI terhadap sampel 1, 2, 6, dan 8 plasmid pT-mga yang menghasilkan dua potongan ukuran $3.015 \mathrm{bp}$ (pGEM T-easy) dan $1.494 \mathrm{bp}$ (gen mga).
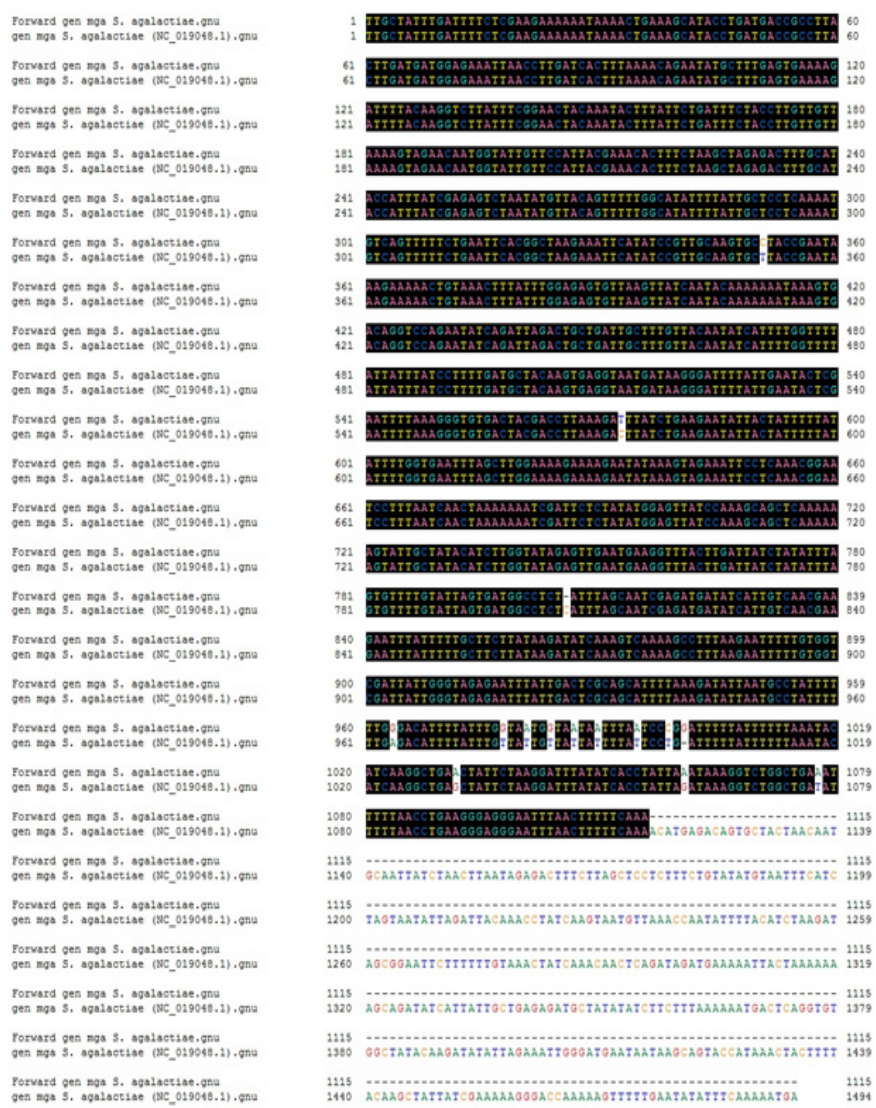

Gambar 4. Alignment sekuens partial gen mga S. agalactiae (dari arah forward, SAF) dengan gen mga S. agalactiae (no. aksesi Bank Gen NC_019048.1). 
mengandung plasmid pMBA-mga ada 24 sampel, yaitu koloni $2,3,5,12,13,17,23,25,28,36$, $37,38,41,42,43,46,47,49,50,52,56,57,58$, dan 59. Pemetaan konstruksi plasmid berhasil dilakukan menggunakan program Snapgene (Gambar 6).

Prinsip dasar proses isolasi plasmid adalah kultur koloni plasmid pada fase log (ketika pembelahan maksimal), kemudian pelet bakteri diberikan perlakuanlisis, neutralisasi, binding, dan elusi. Verifikasi kembali dilakukan menggunakan PCR dengan template DNA plasmid dan primer gen mga. Verifikasi berikutnya adalah melakukan restriksi plasmid pMBA-gen mga menggunakan enzim SalI dan NotI. Berdasarkan hasil restriksi diperoleh dua potongan berupa 7.000 bp plasmid pMBA dan 1.494 bp gen mga. Kandidat vaksin
DNA $S$. agalactiae yang berupa koloni yang mengandung plasmid ada 24 koloni. Masingmasing plasmid dari 24 koloni tersebut telah berhasil dilakukan pengukuran konsentrasi plasmid dengan besar 21,45-252,09 ng/ $\mu \mathrm{L}$ dan memiliki kemurnian yang bagus dengan kisaran perbandingan A260/280 adalah 1,91-2,00. Kemurnian DNA yang baik berkisar antara 1,82,00 (Sambrook et al., 1999).

Vektor yang digunakan sebagai pembawa gen mga telah berhasil digunakan sebagai vektor pembawa gen glikoprotein 25 pada vaksin DNA untuk penyakit koi herpes virus (KHV) (Nuryati et al., 2010). Oleh sebab itu, vektor tersebut digunakan dalam proses konstruksi vaksin DNA untuk mengendalikan infeksi $S$. agalactiae pada ikan nila. Gen mga yang menyandikan $\mathrm{M}$ protein
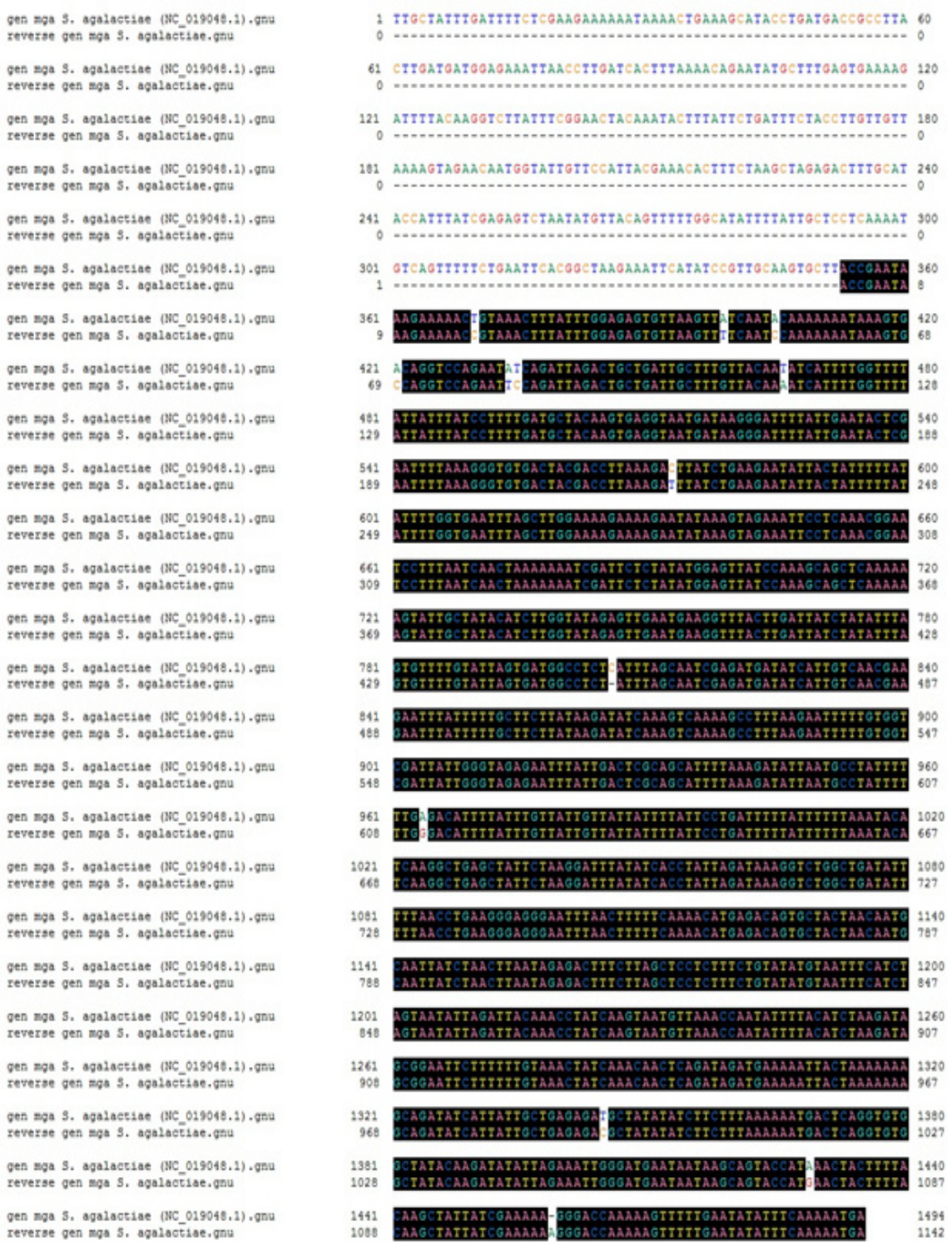

Gambar 4. Alignment sekuens partial gen mga S. agalactiae (dari arah forward, SAF) dengan gen mga S. agalactiae (no. Aksesi Bank Gen NC_019048.1). 


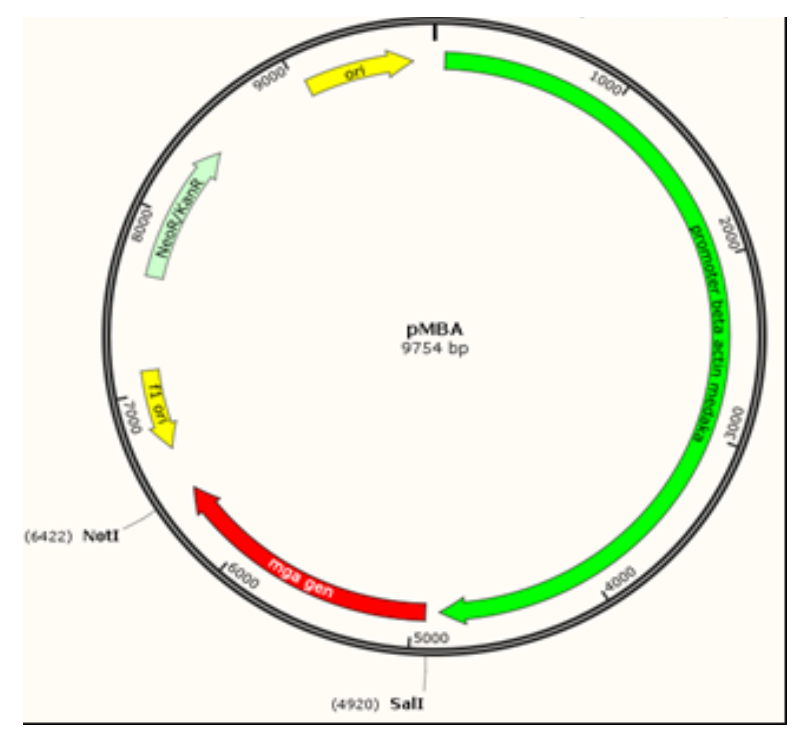

Gambar 6. Konstruksi plasmid pMBA dan gen mga.

merupakan faktor virulensi pada S. agalactiae. $M$ protein bersifat immunogenik dan memiliki kemampuan untuk menghindari sel fagositosis pada sistem imun ikan.

\section{KESIMPULAN}

Kloning gen mga Streptococcus agalactiae isolat lokal telah berhasil dilakukan sebagai bahan dasar vaksin DNA. Konstruksi gen mga yang dikendalikan oleh promoter MBA telah berhasil dibuat dan ini merupakan kandidat vaksin DNA untuk mengendalikan infeksi $S$. agalactiae pada ikan nila.

\section{UCAPAN TERIMA KASIH}

Kami menyampaikan banyak terima kasih kepada Dr. Alimuddin untuk vektor yang digunakan dan tim vaksin BPPT. Penelitian ini dibiayai oleh DIPA BPPT 2013.

\section{DAFTAR PUSTAKA}

Abdulhaqq SA, Weiner DB. 2008. DNA vaccines: developing new strategies to enhance immune responses. Immunologic Research 42: 219232.

Claveri JM, Notredame C. 2003. Bioinformatics for dummies. $2^{\text {nd }}$ ed. New York: John Willey Publisher.

Evans JJ, Klesius PH, Pasnik DJ, Bohnsack JF. 2009. Human Streptococcus agalactiae isolate in Nile tilapia Oreochromis niloticus. Emerging Infectious Diseases 15: 774-776.
EyngorM, Tekoah Y, Shapira R, Hurvitz A,Zlotkin A, Lublin A, Eldar A. 2008. Emergence of novel Streptococcus iniae exopolysaccharideproducing strains following vaccination with nonproducing strains. Journal Applied and Environmental Microbiology 74: 6.8926.897.

Hardi EH, Harris E, Lusiastuti AM. 2013. Kandidat vaksin potensial Streptococcus agalactiae untuk pencegahan penyakit streptococcosis pada ikan nila Oreochromis niloticus. Jurnal Veteriner 14: 408-416.

Johri AK, Paoletti LC, Glaser P, Dua M, Sharma PK, Grandi G, Rappuoli R. 2006. Group B Streptococcus: global incidence and vaccine. Natural Review Microbiology 4: 932-942.

Kurath G. 2008. Biotechnology and DNA vaccines for aquatic animals. Revue Scientifique et Technique-Office International des Épizooties 27: 175-196.

Nobbs AH, Lamont RJ, Jenkinson HF. 2009. Streptococcus adherence and colonization. Microbial Molecular Biology Reviews 73: 407-450.

Nuryati S, Alimuddin, Sukenda, Soejoedono RD, Santika A, Pasaribu FH. 2010. Construction of a DNA vaccine using glycoprotein gene and its expression towards increasing survival rate of KHV-infected common carp Cyprinus carpio. Jurnal Natur Indonesia 13: 47-52.

Nuswantoro S, Yuhana M, Santika A, Nuryati S, Zainun Z, Mawardi M. 2012. Efficacy of DNA vaccine encoding koi herpesvirus glycoprotein GP-25 in common carp juvenile by immersion. Jurnal Akuakultur Indonesia 
11: 76-85.

Patel V, Valentin A, Kulkarni V, Rosati M, Bergamaschi C, Jalah R, Alicea C, Minang JT, Trivett MT, Ohlen C, Zhao J, RobertGuroff M, Khan AS, Draghia-Akli R, Felber BK, Pavlakis GN. 2010. Long-lasting humoral and cellular immune responses and mucosal dissemination after intramuscular DNA immunization. Vaccine 28: 4.827-4.836.

Pokorna D, Rubio I, Müller M. 2008. DNAvaccination via tattooing induces stronger humoral and cellular immune responses than intramuscular delivery supported by molecular adjuvants. Genetic Vaccines and Therapy 6: $1-8$.

Prieto AI, Kahramanoglou C, Ali RM, Fraser GM, Seshasayee AS, Luscombe NM. 2012. Genomic analysis of DNA binding and gene regulation by homologous nucleoid-associated proteins IHF and HU in Escherichia coli K12. Nucleic Acids Research 40: 3.524-3.537.

Sambrook J, Fritsch EF, Maniatis T. 1999. Molecular Cloning. $2^{\text {nd }}$ ed. New York: Cold Springs Harbor Laboratory.

Tonheim TC, Bøgwald J, Dalmo RA. 2008. What happens to the DNA vaccine in fish? A review of current knowledge. Fish and Shellfish Immunology 25: 1-18.

Wang S, Kennedy JS, West K, Montefiori DC, Coley S, Lawrence J, Shen S, Green S, Rothman AL, Ennis FA, Arthos J, Pal R, Markham P, Lu S. 2008. Cross-subtype antibody and cellular immune responses induced by a polyvalent DNA prime-protein boost HIV-1 vaccine in healthy human volunteers. Vaccine 26: 3.9473.957 . 